\title{
Epilepsy and Sport in Childhood
}

\author{
Dr Michael Finlay Allen \\ Mr George William Finlay Guiton
}

\section{Epilepsy triggers are difficult to quantify; Literature shows that exercise is rarely a stimulus}

The benefits of exercise to children suffering with epilepsy (CWEs) are well documented through research:

- Better seizure control

- Reduction in epileptiform discharges on EEG

- Positive impact on psychosocial functioning

- Improved cognitive function

- Development of interpersonal skills

In our society, CWEs may have been prevented from undertaking exercise for a variety of reasons:

- Anxiety of having a seizure

- Conflicting advice from Doctors

- Exclusion by teachers

- Overprotection from family
The impacts to CWEs not taking part in physical exercise can cause them serious harm:

- Obesity

- Increased risk of heart disease and diabetes

- Limitations to psychosocial development

- Increase in frequency and severity of seizures

As doctors it is important to be able to give balanced advice to our patients on the risks and benefits of participating in sport.

The following categorization has been made to enable health professionals to safely encourage children with epilepsy to take part in sport.

\begin{tabular}{|c|c|c|}
\hline $\begin{array}{c}\text { Group 1 sports } \\
\text { (no significant additional } \\
\text { risk to CWEs) }\end{array}$ & $\begin{array}{c}\text { Group } 2 \text { sports } \\
\text { (moderate risks to the } \\
\text { CWEs but not to } \\
\text { bystanders) }\end{array}$ & $\begin{array}{c}\text { Group 3 sports } \\
\text { (high risk for CWEs, and, } \\
\text { for some sports, also for } \\
\text { bystanders) }\end{array}$ \\
\hline $\begin{array}{c}\text { Sports that do not involve high } \\
\text { speeds or dangerous equipment } \\
\text { e.g. Judo, Football and Bowling. }\end{array}$ & $\begin{array}{c}\text { Sports that involve high speeds, } \\
\text { personal injury or dangerous } \\
\text { equipment e.g. Archery, } \\
\text { Snowboarding or Boxing. }\end{array}$ & $\begin{array}{c}\text { Sports that involve extreme } \\
\text { speeds or environments e.g. } \\
\text { Scuba Diving, Paragliding or } \\
\text { Motor Sports. }\end{array}$ \\
\hline $\begin{array}{c}\text { Generally permitted unless } \\
\text { epilepsy is triggered by certain } \\
\text { activities. }\end{array}$ & $\begin{array}{c}\text { Generally permitted at } \\
\text { neurologist's discretion with } \\
\text { restrictions. }\end{array}$ & $\begin{array}{c}\text { Generally not permitted, but } \\
\text { exceptions may be taken at } \\
\text { neurologist's discretion for } \\
\text { sports with no risk to } \\
\text { bystanders. }\end{array}$ \\
\hline
\end{tabular}

\section{References}

1. Arida RM, Scorza FA, Cavalheiro EA. Role of physical exercise as complementary treatment for epilepsy and other brain disorders. Curr Pharm Des. 2013;19(38):6720-5.

2. Elliott JO, Lu BJ, Moore JL, et al. Exercise, diet, health behaviors, and risk factors among persons with epilepsy based on the California Health Interview Survey, 2005. Epilepsy Behav 2008;13:307-315

3. International League Against Epilepsy

4. Nakken KO, Løyning A, Løyning T, et al. Does physical exercise influence the occurrence of epileptiform EEG discharges in children? Epilepsia 1997;38:279-284

5. Nakken KO. Physical exercise in outpatients with epilepsy. Epilepsia 1999;40:643-651

6. Pimentel J, Tojal R, Morgado J. Epilepsy and physical exercise. Seizure. 2015 Feb;25:87-94.

Tsuji S. Participation of People with Epilepsy in Sports. Brain Nerve. 2017 Feb;69(2):151-158

8. Vancini RL, de Lira CA, Scorza FA, et al. Cardiorespiratory and electroencephalographic responses to exhaustive acute physical exercise in people with temporal lobe epilepsy. Epilepsy Behav2010;19:504-508 